\title{
Pedagogical conditions for the formation of professional and personal identity of teachers of additional education
}

\author{
T.A. Maslova ${ }^{1 *}$, and V.A. Romanov ${ }^{2}$ \\ ${ }^{1}$ V.I. Kaluga State University named after K.E. Tsiolkovsky, Kaluga, Russia \\ ${ }^{2}$ V.I. Tula State Pedagogical University named after L.N. Tolstoy, Tula, Russia
}

\begin{abstract}
The article discusses and describes in detail the pedagogical conditions that affect the formation of professional and personal identity of teachers of additional education. Various scientific approaches to understanding pedagogical conditions are analyzed. The author describes the most relevant interactive forms of professional and personal identity formation. The article recommends the program of professional development "ABC of professional and personal growth" and the technologies of its implementation.
\end{abstract}

\section{A problem statement}

At the present stage of the development of education, the path to success in the implementation of pedagogical activities largely depends on the formation of a stable and strong professional identity among teachers. Professional and personal identity is one of the factors that affect a person's self-realization in their profession [1-4].

The changes taking place in the Russian society lead to an increase in the requirements for the professionalism of specialists, to the need to include them in the constant process of self-development, self-education and self-design.

In this issue, the most important role is played by the qualitative process of professional and personal reflection of teachers. The success of the teacher in the profession and his competence in solving modern problems of society depends on how much the teacher is focused on his professional activity, understands its value and social significance, and is ready for professional self-development.

The system of additional education is beginning to play an increasingly important role in domestic education.

Therefore, the solution of the problem of formation of professional and personal identity of teachers of additional education comes to the fore.

Studies show that for the effective implementation of this process, it is necessary to organize special pedagogical conditions under which it becomes possible to truly selfknowledge of the individual in the course of his professional activity.

\footnotetext{
*Corresponding author: prof-ped.gpa@mail.ru
} 
This problem seems to us particularly relevant, because modern research reveals an insufficiently effective identification process in a significant number of modern teachers, expressed in the fact that specialists do not always fully understand their own personal resources, poorly identify themselves with the professional ideal, do not fully realize their belonging to the teaching profession and find it difficult to determine what their personal and professional identity is.

Thus, it can be stated that the contradiction between the increased requirements for the level of development of professional and personal identity of teachers and the insufficient development of scientific and methodological approaches to its formation, especially in the context of working with teachers of additional education, has become more acute.

This is reflected in the fact that the professional and personal identity of teachers remains a poorly controlled process, as a result of which teachers do not fully realize their individual opportunities for professional growth, which can lead to a crisis in the professional development of a teacher.

\subsection{The objective of the work}

Studies of the process of identity formation have their own history. In Russian and foreign literature, philosophers, sociologists, and psychologists, such as E. Erikson, J.P. Sartre, E. Fromm, R.M. Aleynik, L.P. Bueva, I.S. Vdovina, I.S. Kohn, O.V. Lukyanov, and many others, address this topic. The problem of formation of professional identity of teachers is reflected in the works of S.I. Arkhangelsky, A.A. Verbitsky, V.A. Slastenin, L.B. Schneider devoted to the complex study of vocational training and education, in the provisions of the concept of personality-oriented education (A.G. Zdravomyslov, D.A. Leontiev, E.L. Rudnev, M.S. Yanitsky, etc.).

Modern science considers professional identity in several directions: the essence of the professional identity of the teacher is analyzed [5-10], various approaches to determining the content of a teacher's professional identity are defined [11-13], research is conducted on the formation and development of pedagogical identity [14-16], it is studied what changes occur in the professional identity of the teacher and how this is related to the reform of education, which, at the present stage, is taking place in many countries [17].

However, the study of the problems of professional and personal identity of teachers of additional education has not been reflected in modern studies.

\section{Results of the research}

The philosophical interpretation of this concept is connected with the relation of the object to the phenomena surrounding it, without which it cannot exist. In psychology, the concept under study is usually presented in the context of mental development and is revealed through a set of internal and external causes that determine the psychological development of a person. Teachers take a similar position to psychologists, considering the condition as a set of variables of natural, social, external and internal influences that affect the physical, moral, and mental development of a person, his behavior, upbringing and training, and personality formation [18].

The concept of "condition" is in the field of view of various sciences, from a pedagogical point of view, by conditions we will understand that this is a set of causes, circumstances, or any objects. Different conditions can affect the processes of education, training and development to different degrees, accelerate or slow down these processes.

Let's consider some of them from the point of view of their relevance for the study and formation of professional and personal identity of teachers. The term "identity" is considered by us as a subjective personal indicator that requires developed skills of 
reflection in an adequate self-assessment in the field of their interests, abilities, goals and values; the ability to regulate and develop their real image of "I" in accordance with the changing in the rapidly developing modern world ideal image of "I".

The analysis of the positions of researchers V.I. Andreev, A.Ya. Nain, N.M. Yakovleva, N.V. Ippolitova, M.V. Zvereva, B.V. Kupriyanov, S.A. Dynina and others regarding the definition of the concept of "pedagogical conditions" allows us to identify a number of provisions that are important for our understanding of this phenomenon:

1) the conditions act as an integral element of the pedagogical system (including the integral pedagogical process);

2) pedagogical conditions reflect the totality of the possibilities of the educational (purposefully designed measures of influence and interaction of the subjects of education: the content, methods, techniques and forms of training and education, software and methodological equipment of the educational process) and material-spatial (educational and technical equipment, natural-spatial environment of an educational institution, etc.) environment that affect positively or negatively its functioning;

3 ) in the structure of pedagogical conditions, there are both internal (providing an impact on the development of the personal sphere of the subjects of the educational process) and external (contributing to the formation of the procedural component of the system) elements;

4) the implementation of correctly chosen pedagogical conditions ensures the development and efficiency of the functioning of the pedagogical system [10]. Thus, we consider pedagogical conditions as one of the components of the pedagogical system, reflecting the totality of the educational and material-spatial environment, affecting the personal and procedural aspects of this system and ensuring its effective functioning and development [18].

The first group of selected conditions consists of organizational and pedagogical conditions, which include:

- a set of objective possibilities that ensures the successful solution of the tasks set (E. I. Kozyreva);

- the set of possibilities of the content, forms, and methods of a holistic pedagogical process aimed at achieving the goals of pedagogical activity (V.A. Belikov);

- the set of objective opportunities for teaching and educating the population, organizational forms and material capabilities;

- fundamental grounds for linking the processes of activity for managing the process of formation of professional and pedagogical culture of the individual (A.V. Sverchkov) [18].

Obviously, in the framework of the organization of purposeful influence on the formation of personal and professional identity of teachers is necessary to consider the organizational and pedagogical conditions, as they offer a focused, plan selection, design and use of the content, methods (techniques) to achieve the goal of teaching activities (S.N. Pavlov) [18].

The second type of pedagogical conditions are psychological and pedagogical conditions (N.V. Zhuravskaya, A.V. Round, A.V. Lysenko, A. Malykhin, etc.). Psychological and pedagogical conditions are considered by scientists as the conditions are designed to accommodate the specific pedagogical interventions on the development of the identity of the subjects or objects of the pedagogical process (teachers or students) which in turn increase the efficiency of educational process [18].

In studies on the problems of modern pedagogy, didactic conditions are particularly considered, which are defined as "the presence of such circumstances, prerequisites, in which, firstly, the existing learning conditions are taken into account, secondly, ways of transforming these conditions in the direction of learning goals are provided, thirdly, content elements, methods (techniques) and organizational forms of learning are selected, 
built and used in a certain way, taking into account the principles of optimization" [18], that is, didactic conditions are the result of purposeful selection, construction and application of content elements, methods (techniques), as well as organizational forms of learning to achieve didactic goals. goals.

These conditions in the framework of our research work should be reflected in the content and instrumental content of the program for the formation of professional and personal identity of teachers of additional education.

For the formation of professional and personal identity among teachers of additional education, at the present stage of development of society, it is necessary to use interactive forms of education and psychological training.

The concept of "interactive" originates from the English word "inter" ("inter" "mutual", "act" - "to act"). Interactive learning is a special form of organizing cognitive activity that involves specific and predictable goals. One of these goals is to create a comfortable learning environment in which the student, or in our context, the teacher, feels his success, his intellectual competence, which makes the learning process itself productive [19].

The use of interactive teaching methods is organized taking into account the involvement of all group members in the learning process, without exception. At the same time, everyone makes their own special individual contribution, in the course of work there is an exchange of knowledge, ideas, methods of activity. Individual, pair and group work is organized, project work, business and role-playing games are used, work is carried out with documents and various sources of information. In the course of the implementation of these forms and methods of work, a special environment of educational communication is created, which is characterized by openness, interaction of participants, equality of their arguments, accumulation of joint knowledge, the possibility of mutual assessment and control [20]. It is such an environment that will contribute to the development of the skills of professional and personal reflection, active self-knowledge and self-acceptance, that is, the formation of the professional and personal identity of teachers.

The following interactive forms can be used to solve educational problems: interactive lecture, brainstorming, interactive excursion, videoconference, round table, focus group method, business games, role-playing games, case-study, educational group discussions, trainings.

The concept of professional and personal identity we are considering includes the following key criteria:

1. The process of identification with the ideal professional and personal image of "I";

2. The process of internal professional and personal reflection;

3. Self-assessment of professional and personal meanings and values that guide the selfdevelopment of an individual:

- motives of professional activity;

- personality orientations within the framework of social labor [21, 22].

The levels of formation of the professional and personal identity of teachers are integrative characteristics identified on the basis of the severity of its key criteria.

The formation of professional identity at a high level is characterized by a pronounced positive correlation with the ideal professional and personal image of "I"; non-alexithymic personality type with a high level of professional reflection; optimal motivational complex with a predominance of internal motives of professional activity; professional focus on work in a real and ideal position.

The formation of professional identity at the middle level is characterized by a pronounced positive correlation with the ideal professional and personal image of "I"; nonalexithymic personality type with an average level of professional reflection; optimal 
motivational complex with a pronounced value of external positive motives of professional activity; professional focus on work in a real and ideal position.

The formation of professional identity at a low level is characterized by a weak or pronounced negative correlation with the ideal professional and personal image of "I"; transitional or alexithymic personality type with a low level of professional reflection; suboptimal or unfavorable motivational complex with a predominance of external negative motives of professional activity; professional focus on exploitation or parasitism in one or both positions.

The conditions for the formation of the professional and personal identity of teachers of the additional education system in the process of their professional activities were implemented in the content of the professional development program "ABC of Professional and Personal Growth" and the technology of its implementation.

The program has a socio-pedagogical, preventive focus. Tasks solved within the program:

1. Actualization of teachers' ideas about their personality based on figurative reflection

2. Actualization of teachers' ideas about their professional qualities on the basis of their own ideas and those of colleagues.

3. Assistance to teachers of continuing education in the implementation of a conscious identification process with an ideal professional image.

4. Help teachers in understanding the role structure of their personality

5. Expanding the ideas of teachers about the role structure of the personality of teachers

6. Assistance to teachers in the formation of a professional "I Image".

7. Assistance to teachers in competent forecasting, construction and achievement of life (including professional) goals.

8. Assistance to teachers in building an individual plan for professional and personal development and predicting its results

9. Development of the skills of introspection among teachers

10. Development of the skills of constructive interaction in the teaching staff in the course of solving professional problems

11. Teaching teachers self-diagnosis techniques based on valid diagnostic techniques

12. Teaching teachers the techniques of relaxation (relieving emotional stress).

The content of the program modules, forms of events and the main methods and techniques of working with teachers of additional education are presented in tables № 1-6.

Table 1. Module: "Identity with an ideal professional image".

\begin{tabular}{|l|l|l|}
\hline \multicolumn{1}{|c|}{ Theme of the event } & Forms of conducting & \multicolumn{1}{|c|}{$\begin{array}{l}\text { Basic methods and } \\
\text { techniques of work }\end{array}$} \\
\hline $\begin{array}{l}\text { "Ideal teacher" - a look from the } \\
\text { inside }\end{array}$ & $\begin{array}{l}\text { Seminar with training } \\
\text { elements }\end{array}$ & $\begin{array}{l}\text { Focus group work; } \\
\text { discussion; visual methods; } \\
\text { rational reflection }\end{array}$ \\
\hline "Voice of the people" & $\begin{array}{l}\text { Filling out the stand "Ideal } \\
\text { teacher" by parent and } \\
\text { students followed by } \\
\text { discussion with teachers }\end{array}$ & $\begin{array}{l}\text { Interviewing parents and } \\
\text { students; conversation }\end{array}$ \\
\hline Theme of the event & Forms of conducting & $\begin{array}{l}\text { Basic methods and } \\
\text { techniques of work }\end{array}$ \\
\hline $\begin{array}{l}\text { Analysis of the content of the } \\
\text { Professional standard for teachers } \\
\text { of additional education for children } \\
\text { and adults Analysis of the content } \\
\text { of the Professional standard for } \\
\text { teachers of additional education for } \\
\text { children and adults }\end{array}$ & Sndividual work & Self-study method relaxation \\
\cline { 2 - 3 } & & $\begin{array}{l}\text { Brainstorm; } \\
\text { exercises; rational reflection }\end{array}$ \\
\hline
\end{tabular}


Table 2. Module: "Self-assessment in professional activity".

\begin{tabular}{|l|l|l|}
\hline \multicolumn{1}{|c|}{ Theme of the event } & \multicolumn{1}{|c|}{ Forms of conducting } & \multicolumn{1}{|c|}{$\begin{array}{l}\text { Basic methods and } \\
\text { techniques of work }\end{array}$} \\
\hline $\begin{array}{l}\text { Psychological and pedagogical } \\
\text { aspects of the formation of self- } \\
\text { esteem }\end{array}$ & Interactive lecture & $\begin{array}{l}\text { Explanatory, visual, } \\
\text { conversation }\end{array}$ \\
\hline I am real and I am perfect & $\begin{array}{l}\text { Individual consultation on the } \\
\text { results of diagnostics according to } \\
\text { the method of researching self- } \\
\text { assessment of personality S.A. } \\
\text { Budassi }\end{array}$ & conversation \\
\hline "My personality map" & $\begin{array}{l}\text { Training with elements of art } \\
\text { therapy }\end{array}$ & $\begin{array}{l}\text { Art-theoretical drawing, } \\
\text { emotional reflection, } \\
\text { self-presentation, } \\
\text { relaxation exercises }\end{array}$ \\
\hline
\end{tabular}

Table 3. Module: "My image in the profession".

\begin{tabular}{|c|c|c|}
\hline Theme of the event & Forms of conducting & $\begin{array}{l}\text { Basic methods and } \\
\text { techniques of work }\end{array}$ \\
\hline $\begin{array}{l}\text { "I am through the eyes of } \\
\text { others" }\end{array}$ & Training & $\begin{array}{l}\text { Game exercises "View } \\
\text { from the side", "Living } \\
\text { mirror"; emotional and } \\
\text { rational reflection; } \\
\text { discussion }\end{array}$ \\
\hline $\begin{array}{l}\text { "Professional personality } \\
\text { type" }\end{array}$ & $\begin{array}{l}\text { Self-diagnosis according to the } \\
\text { method "Constructive drawing of a } \\
\text { person from geometric figures"; } \\
\text { individual consultation }\end{array}$ & Testing, conversation \\
\hline "Business card" & $\begin{array}{l}\text { Business game (imitation of a } \\
\text { professional skill competition) }\end{array}$ & $\begin{array}{l}\text { Introspection, self- } \\
\text { presentation, discussion }\end{array}$ \\
\hline $\begin{array}{l}\text { "Me and my profession in a } \\
\text { time perspective" }\end{array}$ & Round table & Group discussion \\
\hline "Pedagogical situations" & Seminar with training elements & $\begin{array}{lr}\text { Group } & \text { case } \\
\text { methodology; relaxation } \\
\text { exercises; rational } \\
\text { reflection }\end{array}$ \\
\hline
\end{tabular}

Table 4. Module: "Me and my goals".

\begin{tabular}{|l|l|l|}
\hline \multicolumn{1}{|c|}{ Theme of the event } & \multicolumn{1}{c|}{$\begin{array}{c}\text { Forms of } \\
\text { conducting }\end{array}$} & \multicolumn{1}{c|}{$\begin{array}{c}\text { Basic methods and techniques of } \\
\text { work }\end{array}$} \\
\hline "Need - motive - goal" & Interactive lecture & Explanatory, visual, conversation \\
\hline $\begin{array}{l}\text { "Technology of turning a } \\
\text { dream into a goal" }\end{array}$ & training & $\begin{array}{l}\text { Algorithm activity; conversation; } \\
\text { rational reflection }\end{array}$ \\
\hline $\begin{array}{l}\text { "Constructing the Purpose of } \\
\text { Life" }\end{array}$ & training & $\begin{array}{l}\text { Algorithm activity; conversation; } \\
\text { rational reflection }\end{array}$ \\
\hline
\end{tabular}

Table 5. Module: "Roles that I play".

\begin{tabular}{|l|l|l|}
\hline \multicolumn{1}{|c|}{ Theme of the event } & \multicolumn{1}{|c|}{$\begin{array}{c}\text { Forms of } \\
\text { conducting }\end{array}$} & $\begin{array}{c}\text { Basic methods and techniques } \\
\text { of work }\end{array}$ \\
\hline "Ten I" & $\begin{array}{l}\text { Seminar with } \\
\text { training elements }\end{array}$ & $\begin{array}{l}\text { Discussion; work according to the } \\
\text { "Circle of my I" algorithm; play } \\
\text { exercises; emotional reflection; } \\
\text { conversation }\end{array}$ \\
\hline
\end{tabular}




\begin{tabular}{|l|l|l|}
\hline $\begin{array}{l}\text { "Roles that people play" (E.Burn's } \\
\text { transactional analysis) }\end{array}$ & $\begin{array}{l}\text { Round table, self- } \\
\text { diagnosis. }\end{array}$ & $\begin{array}{l}\text { Explanatory, visual, discussion; } \\
\text { rational reflection }\end{array}$ \\
\hline $\begin{array}{l}\text { "Pedagogical situations" (resolution } \\
\text { based on transactional analysis) }\end{array}$ & Pedagogical training & Group case-method, reflection \\
\hline
\end{tabular}

Table 6. Module: "Building an individual plan for self-development".

\begin{tabular}{|c|c|c|}
\hline Theme of the event & $\begin{array}{l}\text { Forms of } \\
\text { conducting }\end{array}$ & $\begin{array}{l}\text { Basic methods and techniques } \\
\text { of work }\end{array}$ \\
\hline \multirow{3}{*}{$\begin{array}{llll}\begin{array}{l}\text { "Individual plan } \\
\text { development" }\end{array} & \text { of } & \text { self- }\end{array}$} & Interactive lecture & Explanatory, visual, conversation \\
\hline & $\begin{array}{l}\text { Individual } \\
\text { consultation }\end{array}$ & Conversation \\
\hline & Conference & Self-presentation, \\
\hline Final lesson & Round table & Discussion, final reflection \\
\hline
\end{tabular}

Each exercise and each stage of work ended with reflection. One of the important results of the implementation of the program was the preparation and presentation by teachers of an individual plan for professional self-development.

\section{Conclusions}

Based on the results of testing the conditions for the formation of professional and personal identity of teachers of additional education within the framework of the program "ABC of Professional and Personal Growth", we formulated the following general guidelines for its implementation.

1. A single form of addressing each other, for example (by name). To create a climate of trust in the group, invite each other to refer to each other by name, including the coach. This psychologically equalizes everyone, including the leader, regardless of age, social status, life experience, and contributes to the liberation of the training participants.

2. "Rule of the ears" - you speak, I listen, I speak - you listen.

3. Communication according to the principle "here and now". During the training, everyone only talks about what worries them right now, and discusses what is happening to them in the group.

4. "The rule of language" is to talk about actions and express your attitude to actions, and not to get personal ("you said ... and I didn't like it").

5. Personification of statements. Impersonal words and expressions such as "Most people believe that ...", we replace them with "I believe that ...", "I think ..." - this will contribute to the sincerity of communication.

6. Confidentiality of everything that happens. Everything that happens during the training is not disclosed or discussed outside the training under any pretext. This will help the participants in the training to be sincere and feel free.

7. Rule of activity - I take part in all types of work of the group.

8. Rule of coming on time - I try not to be late.

The system of additional education is beginning to play an increasingly important role in national education. The Professional Standard of the teacher of additional education for children and adults was adopted (Order of the Ministry of Labor and Social Protection of the Russian Federation of September 8, 2015 N 613n), which reflects the requirements for the professional and personal qualities of teachers. The Concept for the Development of Additional Education in the Russian Federation states that it is "additional education that acts as a mechanism for the formation of values, worldview and identity of the younger generation". 
Therefore, the solution to the problem of forming the professional and personal identity of teachers of additional education comes to the fore. The teacher's success in the profession and his competence in solving modern problems of society depend on how much the teacher is focused on his professional activity, realizes its value and social significance, is ready for professional self-development.

\section{References}

1. N.I. Mitskevich, Methods of active adult education, An educational and methodological manual (2012)

2. N.V. Antonova, Personal identity of a modern teacher and features of his communication, Questions of psychology, 6, 23-30 (1997)

3. A.A. Verbitsky, The place and role of the teacher in the process of education reform, Bulletin of the Moscow State University for the Humanities named after, 2, 42-51 (2014)

4. N. Ippolitova, N. Sterkhova, Analysis of the concept of "pedagogical conditions", essence, classification, Higher and professional education, 1, 8-14 (2012)

5. N.L. Regush, Professional identity of a teacher at different stages of pedagogical activity, 167 (2002)

6. A. Pipere, Identity of Learning Teacher, Examining Structural Variations and Interactive "Self", The Irish Journal of Psychology, 24(3-4), 143-160 (2003)

7. R.E. Buitrago-Bonilla, R.N. Cárdenas-Soler, Emociones e identidad profesional docente: relaciones e incidencia, Praxis \& Saber, 8(17), 225-247 (2017)

8. M.J. Fernandes Gonzalez, Biprofesionalas identitates integrācijas veicinasana studiju procesa, 790 (2013)

9. C. Beauchamp, L. Thomas, Understanding teacher identity, An overview of Issues in the literature and implications for teacher education, Cambridge Journal of Education, 39, 175-189 (2009)

10. M. Voinea, T. Palasan, Teachers' professional identity in the 21st century Romania, Procedia, Social and Behavioral Sciences, 128, 361-365 (2014)

11. M. Prytula, K. Weiman, Collaborative professional development, An examination of changes in teacher identity through the professional learning community model, Journal of case studies in education, 3, 1-19 (2012)

12. N. Aykac, Understanding the Underlying Factors Affecting the Perception of PreService Teachers', University Bulletin, 6(1), 67-78 (2017)

13. S.D. Polyakov, In search of pedagogical innovation, 200 (2003)

14. Yu.N. Lapygin, Methods of active learning, Textbook and practice, 240 (2016)

15. A.I. Zhuk, Active methods of teaching in the system of professional development of teachers: textbook, 150 (2014)

16. B. Li, Identifiable but Changeable, Capturing the Features of Teacher Identity, International J. Soc. Sci. \& Education, 6(2), 225-234 (2016)

17. Personal and Professional Selves, Toronto, The University of Toronto (2011)

18. N.L Ivanova, Professional identity in current research, Voprosy psikhologii, 1, 89$101(2008)$ 
19. L.S. Ilyushin, A.A. Azbel, The modern Russian teacher: Studying awareness with the use of the semi-structured interview, Psychology in Russia: State of the Art, 10(1), 4966 (2017)

20. B. Hsieh, The Importance of Orientation, Implications of Professional Identity on Classroom Practice and for Professional Learning, Teachers and Teaching, Theory and Practice, 21(2), 178-190 (2015)

21. B. Olsen, Teaching for Success, Developing Your Teacher Identity in Today's Classroom, 200 (2016)

22. A.S. Voronin, Dictionary of terms in general and social pedagogy, 140 (2006) 